\title{
Extraction, Nanoemulsion Development and the Toxicity of Cashew Nut Shell Liquid (CNSL) to Maize Weevil Sitophilus zeamais
}

\author{
Dian Astriani ${ }^{\#, *}$, Edhi Martono ${ }^{\#}$, Tri Harjaka ${ }^{\#}$, Witjaksono ${ }^{\#}$

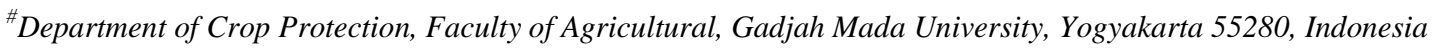 \\ Email: astrianidian67@gmail.com; edhi.martono@ugm.ac.id; triharjaka@ugm.ac.id; witjaksono@ugm.ac.id \\ "Department of Agrotechnology, Faculty of Agroindustry, University of Mercu Buana Yogyakarta, Yogyakarta, Indonesia \\ E-mail: 1astrianidian67@gmail.com
}

\begin{abstract}
Cashew Nut Shell Liquid (CNSL) is a complex long branch and unsaturated phenolic compound with insecticidal potential. The main toxic component of CNSL is anacardic acid and its recovery amount is influenced by the extraction processes. Currently, mechanical extraction is the most effective and efficient technique for extracting CNSL from cashew nut shells. This study was conducted to observe the characteristics of CNSL as a botanical insecticide. This study aimed to determine toxicity and develop a nanoemulsion formulation for maize weevil (Sitophilus zeamais) control. Cashew nut shells were cut into $2-3 \mathrm{~cm}$ and heated at $80 \mathrm{oC}$ in a oven for 8 hours until moisture content reached $12.8 \%$. In each process, 3 extractions were carried out using a mechanical centrifugal press (Honda GX $160 \mathrm{H1}$, Capacity: $0.6 \mathrm{~L}$ ). Then the average CNSL extracted was calculated. An HPLC analysis was carried out to identify anacardic acid in CNSL extracts The results showed that CNSL extracted from cashew nut shell in this study ranged from $16.67-21.15 \%$, with an average of $18.43 \%$. The type of organic solvent used in CNSL formulation affected its toxicity against maize weevil. Compared to the methanol and ethanol solvents, acetone resulted in the highest toxicity of CNSL formulations with LC50 contact and feed respectively $32855(2466$ - 4036) ppm and 54750 (4287 - 6161) ppm. The CNSL nanoemulsions formulations has the potential to increase its toxicity against maize weevil. CNSL nanoformulation with heating treatment resulted in lower anacardic acid and lower toxicity against maize weevil by $<60 \%$ compared with a similar formulation without heating.
\end{abstract}

Keywords-CNSL; extraction; nanoemulsion; toxicity; Sitophilus zeamais.

\section{INTRODUCTION}

Indonesia has great potential to produce cashew nutshell extraction product termed cashew nut shell liquid oil or more well known as Cashew Nut Shell Liquid (CNSL). Each cashew fruit might contain $45-67 \%$ of cashew shells and CNSL content in the shell range between $18-30 \%[1,2]$. Cashew fruit production in 2015 reached 123,400 tons, the total area of cashew plantations in Indonesia in 2016 reached 526336 ha, with a production of 123549 tons of logs [3]. So that it will get about $55597.05-82777.83$ tons of cashew shells containing CNSL around 10,007.469-30,627.797 tons.

CNSL is a complex phenolic compound containing long branched carbon chains. CNSL is a viscous to viscous sticky liquid, blackish brown, bitter, spicy, very reactive in oxidation or polymerization reactions, and corrosive. However, this corrosive nature can be reduced by heating treatments due to the decarboxylation process which changes anacardic acid into soft cardanol [4,5]. The CNSL consists of several main components, such as anacardic acid (6-peecylsalicyclic acid), cardol (5-pentadecylresorcinol), 2methyl cardol (2-methyl-5-pentadecylresorcinol) and cardanol (3-pentadecylphenol) [6] and their structures are shown in Figure 1. Natural phenol compounds contained in cashew nut shells have unique properties, which are essential in the industrial field and also have pesticide properties such as anti-bacterial properties [1]. Cardanol has also been shown to have anti-proliferation effects on cancer cells, which may cause its derivatives to evolve and act as alternative therapies for anticancer treatment [7]. Recent research has reported that anacardic acid is very promising as a supplement to slow the initiation or development of pancreatic cancer [8].

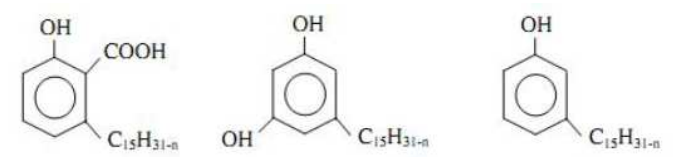

Fig. 1 Chemical structure of CNSL main constituent components [9]

Various methods of extracting active ingredients from plants have been developed with both mechanical and chemical processes. The optimum method for extracting active ingredients effective and efficiently depends mainly on the compound's thermal stability and targeted raw material to be extracted [10]. Various methods can be used 
to extract CNSL, such as by baking, frying, pressing, or using organic solvents. However, roasting cashew at high temperatures, results in low quality CNSL which has dark colors. The pressing method requires preliminary treatments that are time-consuming. In addition, oil is still left in the pulp and water content is also still high.

Meanwhile, extraction using organic solvents produces oil will produce better quality products than using roasting and pressing methods, but costly [4], [11], [12]. The mechanical method using a pressing device produces CNSL with higher viscosity and faster, inexpensive, and practical whereas with chemical methods, although the yield is higher, the density is lower and is 10 times more expensive and 2.5 times longer. Research has shown that CNSL toxicity against Sitophilus spp. resulted from mechanical extraction was higher than CNSL extracted from chemical extraction [13].

Maize weevil is the most important pest in corn seed storage and has caused detrimental loss to several varieties of corn. Seed treatments using insecticides is a frequently used management technique [14]. However, the continuous use of synthetic insecticide may have adverse effects to the environment and human health. Therefore, it is necessary to explore plant extracts as botanical insecticides to substitute synthetic insecticides in the management of this pest.

Botanical insecticides have several disadvantages when compared to synthetic insecticides, such as are relatively less stable, more quickly degrade under environmental pressures, due to oxidative reactions or polymerization reactions [15]. However, botanical insecticides degradable characteristics have their benefits in reducing its risks to non-target organisms. Besides, botanical insecticides generally have multiple modes of actions; therefore, reducing the possibility of developing pest resistance [16]. The synthetic insecticides and botanical extracts can very well integrate into the management because they can conserve natural enemies of pests [17]. Although in general botanical insecticides may have lower toxicity than synthetic insecticides, but they can interrupt insect physiology like reducing protein content in the larval body, interfere grow and development of an insect, until it causes mortality and reduces pest population [18].

Development CNSL formulations as seed treatment pesticides require a broad range of information on the characteristics of CNSL, formulation components, and their effect on maize weevil toxicity. One way to overcome low absorption and instability of formulas is by developing the active ingredients into micro and nano-size formulation [19]. Nanotechnology reduces particle size and is expected to increase the efficiency of active compounds [20]. Smaller particle sizes will widen the surfaces causing an increase in stability, absorption, clarity, and improve the sensory quality and physiological properties of the components [21]. Research showed that citronella nanoemulsion was able to cause higher inhibition to Potyviruses, the mosaic disease pathogen in patchouli, oil formulation at the same dose implying that nanoemulsion formulation has the potential to increase pest control effectiveness [19].

The nanoformulation technique can be carried out with a low energy phase inversion technique. Nano pesticides will then consist of small particles from active ingredients functional structures that act as pesticides [20]. Nanoemulsion technology is expected to contribute to improving the environment and lowering pest control costs [22]. This study aimed to determine various characteristics of CNSL, such as anacardic acid compound content, its toxicity as a botanical pesticide seed treatment against maize weevils in corn seeds, and to develop of CNSL nanoformulation.

\section{MATERIAL AND METHOD}

\section{A. Cashew Seed Extraction}

The main ingredient used was cashew nutshell, which was waste from cashew farmers in Mojolegi Sub-village, Karang Tengah Village, Imogiri District, Bantul Regency, Special Region of Yogyakarta Province. The cashew seeds are from local types of cashews that were harvested during the dry season.

The main extraction device used was pressing device petrol, an oven, a knife, and a set of tools for the identification and analysis of anacardic acid content of CNSL by HPLC. Tools used to analyze the characteristics and quality of CNSL, included viscometer. Cashew nutshell preparation was done to obtain optimal extraction results by achieving optimum water to maintain cell permeability. Besides, sufficient water content will encourage protein denaturation within cell walls which makes it easier to extract CNSL.

Cashew nut shells were cut into $2-3 \mathrm{~cm}$ and heated at $80^{\circ} \mathrm{C}$ in an oven for 8 hours until moisture content reached $12.8 \%$. In each process, 3 extractions were carried out using a mechanical centrifugal press (Honda GX 160 H1, Capacity: $0.6 \mathrm{~L}$ ). Then the average CNSL extracted was calculated. The yield was calculated by modifying formula (1) from [23] as below:

$$
\text { Yield }=\frac{\text { Woight of CNSE (g) }}{\text { Weight of cashew mut shell }(g)} \times 100 \%
$$

An HPLC analysis was carried out to identify anacardic acid in CNSL extracts. Initially, 1 gram of powder sample was taken, dissolved in $100 \mathrm{~mL}$ of methanol and sonicated. Samples were filtered, $5 \mathrm{~mL}$ was taken and dissolved to 10 $\mathrm{mL}$. Subsequently, $1 \mathrm{~mL}$ was taken and diluted in $10 \mathrm{~mL}$. Results were analyzed using a reverse-phase HighPerformance Liquid Chromatography (Water Alliance) with a column C18 MS-II 4.6ID x $150 \mathrm{~mm}$. The mobile phase used was methanol:aquadest (95: 5) with a flow rate of $0.500 \mathrm{~mL}$ per minute. Wavelength was set at $279 \mathrm{~nm}$. Determination of the standard curve using standard anacardic acid with a concentration of $125 ; 100 ; 75 ; 50$; and $25 \mathrm{ppm}$. Then the results were calculated based on the standard curve.

\section{B. CNSL Formulation with Organic Solvent}

CNSL formulations were studied with pure CNSL as a technical active ingredient and the addition of additional ingredients (inert ingredient) with various types of solvent. Several types of organic solvent compounds tested were acetone, methanol and ethanol by volume ratio (CNSL: solvent $)=(1: 1)$. The solutions were then considered as $100 \%$ Stock Solution (SS). Each CNSL formulation with 
various solvents was tested for toxicity against maize weevil as a corn seed treatment insecticide.

\section{CNSL Nano formulation}

CNSL nanoformulation was based on the procedure for pomegranate oil nanoformulation with modifications [24]. The ingredients used were CNSL, Tween 80 (Pharmacetic Quality, Bratachem), PEG 400 (Pharmacetic Quality, Bratachem), LCT oil (virgin coconut oil) (Technical Quality, Tekun Jaya), and Aqua Pi. The composition of CNSL nanoemulsion formulations as shown in Table 1.

CNSL nanoemulsion was produced by inserting Tween 80 , PEG 400, CNSL, and LCT oil into a beaker glass and mixed using a magnetic stirrer for 10 minutes at a speed of 1000 rpm. After 10 minutes, the aqua pi was slightly added and the stirring speed was increased to $1250 \mathrm{rpm}$ for 10 minutes. All ingredients were then homogenized for 2 minutes and followed by sonication for 40 minutes while stirring occasionally. After homogenized and sonicated; $\mathrm{pH}$ test, nanoemulsion type test, the percent transmittance test, the turbidity, and viscosity tests were done.

TABLE I

COMPOSITION OF CNSL NANOEMULSION FORMULATION

\begin{tabular}{|c|l|c|}
\hline No & \multicolumn{1}{|c|}{ Components } & Composition \\
\hline 1 & $\begin{array}{l}\text { Cashew Nut Shell Liquid } \\
\text { (CNSL) }\end{array}$ & $0.03 \mathrm{~g}$ \\
\hline 2 & VCO (virgin coconut oil) & $3 \mathrm{~mL}$ \\
\hline 3 & Tween 80 & $16 \mathrm{~mL}$ \\
\hline 4 & PEG 400 & $8 \mathrm{~mL}$ \\
\hline 5 & Aqua pi & $73 \mathrm{~mL}$ \\
\hline
\end{tabular}

Samples were measured for their $\mathrm{pH}$ by using a $\mathrm{pH}$ meter. Prior to use, the electrodes were calibrated using standard $\mathrm{pH}$ buffers 4 and 7 . The calibration process was complete when the $\mathrm{pH}$ values listed on the screen were in accordance with the value of buffer standard $\mathrm{pH}$ and stable. The electrode was dipped into the samples and $\mathrm{pH}$ values were recorded.

Nanoemulsion type testing was carried out using a dilution method. This test was carried out by dissolving samples into the water phase (1: 100) and oil phase (1: 100). If samples are completely dissolved in the aquadest, the nanoemulsion type was classified as the oil in water (O/W) type, whereas if samples completely dissolved in the oil phase, the nanoemulsion type was classified as the water in oil (W/O) type.

The transmittance test was done by taking a $1 \mathrm{~mL}$ sample and dissolving it in a $100 \mathrm{~mL}$ measuring flask using Aquadest. The solution was measured in percent transmittance at a wavelength of $650 \mathrm{~nm}$ using a UV-Vis spectrophotometer. Aquadest was used as a blank when testing.

Turbidity was determined by measuring the absorbance of the sample using a UV-Vis spectrophotometer at the wavelength of $502 \mathrm{~nm}$. Turbidity was calculated the formula of: turbidity $(\%) \times$ cuvette width $(\mathrm{cm})=2,303 \times$ absorbance [24].

Viscosity: Viscosity measurements were carried out using a Merlin VR viscometer. A total of $14 \mathrm{~mL}$ of the sample was placed into a cup and installed in an existing solvent trap.
The Merlin VR viscometer was set at $200 \mathrm{rpm}, 3$ turns, for 30 seconds.

CNSL nanoemulsion formulation used 2 treatments, which are heated and without heating. Heating was done $<60^{\circ} \mathrm{C}$ and Ultraturrax. Each of these nano emulsions were tested for anacardic acid identification in CNSL nano emulsions by HPLC analysis and seed treatment toxicity against to maize weevil. Experimental procedures are presented in Figure 2.

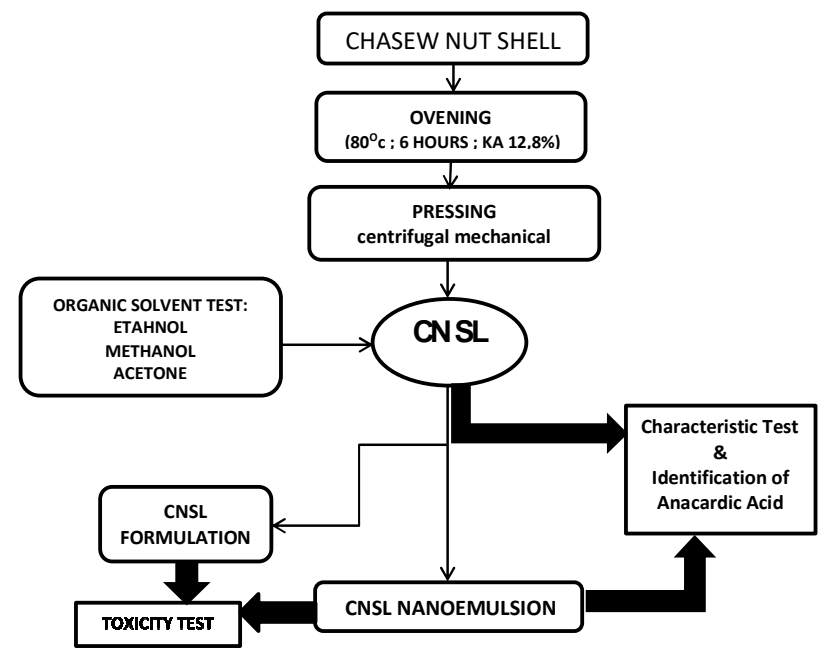

Fig. 2 Experimental procedure

\section{Toxicity Test}

Contact toxicity of CNSL against adult maize weevils was evaluated using topical application. Weevil were stored in a freezer for 1 minute to reduce activity. Bioassay was done by applying approximately $0.5 \mathrm{ml}$ of CNSL extract on 20 adults (10 female and male pairs) imago maize weevils aged 7-15 days. Application was carried out topically on the dorsal thorax of the insect using microsyringes (Hamilton) so that the body surface of corn powder was exposed to CNSL in contact [25]. The test insects were then transferred to a petri dish and stored in an incubator.

A series of CNSL formulation (CNSL-solvent) of $100 \%$, $90 \%, 80 \%, 70 \%, 60 \%, 50 \%, 40 \%, 30 \%, 20 \%, 10 \%, 0 \%$ (solvent only) and an untreated control for 4 replications. After 24 hours the mortality rate of maize weevils was observed. The insect was considered dead when no leg or antennas movements are observed.

Oral toxicity test was done by applying CNSL formulation on $20 \mathrm{gr}$ of corn seeds and 20 maize weevils (10 pairs of females and males) aged 7-15 days. The CNSL volume applied was $1 \mathrm{~mL} / 20 \mathrm{gr}$ of corn seeds to ensure solutions were evenly distributed among seeds Concentrations used in the test were similar to the contact test starting from $0 \%$ to $100 \%$ with 4 replications at each concentration. After being treated with CNSL extracts, corn seeds were air-dried to ensure seed water content did not exceed $12 \%$. The corn seeds were then stored in a tightly closed container. Imago or adult maize weevil mortality was observed from 1-7 days after treatment.

Maize weevil's imago mortality percentage was calculated by the formula in [26] and corrected for natural death using the Abbott formula [26], respectively with equations (2) and (3) below. 
Actual mortality of insects tested $(\%)=\frac{\sum D \text { ead insects }}{\sum \text { Total of insect testel }} \times 100 \%$

If paralysis/death rates in the control group were less than $5 \%$, then mortality was ignored. If the paralysis/death rates in the control group were more than $20 \%$, then the experiments were repeated, and if the paralysis/death rate in the control group was between $5-20 \%$ then it is corrected by the Abbot formula (3):

$$
\text { Corrated mortality }(\%)=\frac{A-C}{100-C} \times 100 \%
$$

$\mathrm{A}=$ paralysis/death rate in the treatment group

$\mathrm{C}=$ paralysis/death rate in the control group

Furthermore, LC50 and LC99 values of contact and feed toxicity were calculated based on mortality that occurred using Probit \& Logit Analysis Polo Plus version 1.0 Copyright 2002-2019 LeOra Software [25].

\section{RESULTS AND DISCUSSIONS}

\section{A. CNSL Yield}

Cashew nut shell oil (CNSL) extracted using a mechanical centrifugal press varied from $16.67-21.15 \%$, with an average of $18.43 \%$. The results showed that CNSL extracted from cashew shell correspond positively (Table 2).

TABLE II

CNSL YIELD FROM VARIOUS WEIGHT SHELL SEEDS

\begin{tabular}{|c|c|c|c|}
\hline No & $\begin{array}{c}\text { Cashew nut shell } \\
\text { weight (kg) }\end{array}$ & $\begin{array}{c}\text { CNSL yield } \\
\text { (kg) }\end{array}$ & Yield (\%) \\
\hline 1 & 1.500 & 0.250 & 16.67 \\
\hline 2 & 2.000 & 0.375 & 18.75 \\
\hline 3 & 4.000 & 0.713 & 17.83 \\
\hline 4 & 6.500 & 1.375 & 21.15 \\
\hline Mean & & & $\mathbf{1 8 . 4 3}$ \\
\hline
\end{tabular}

The initial temperature treatment and material moisture content before pressing will affect the yield amount and quality of CNSL. In this study, the initial heating treatment of extraction was $80^{\circ} \mathrm{C}$, while its moisture content was $12.8 \%$ which according to previous reports, were decent pretreatments [4], [27]. Pressing will cause remaining oil in pulp to be $10 \%$ and water content is still high based on results of CNSL production research conducted by pressing at a pressure of $200 \mathrm{~kg} / \mathrm{cm} 2$ resulting in yields that are still quite low $(19.6 \%)$ [11].

\section{B. CNSL Characteristics}

The characteristics of CNSL used in this study are characteristic generally used to assess the oil quality, namely the saponification rates, iodine numbers, acid numbers, specific gravity, and viscosity. CNSL nanoemulsion formulation possessed lower values because the formulation is not like oil and the concentration of CNSL is deficient.

The saponification number indicates the number of bases needed to lather oils, which is expressed in milligrams of hydroxide needed to soak up one gram of oil or fat [27]. Higher saponification value indicates greater anacardic acid content. The magnitude of the saponification number depends on the molecular weight. Oil which has a low molecular weight, will have a higher saponification number than oil with higher molecular weight [3].

Anacardic acid is a component in CNSL that is quickly soaked causing a decrease of anacardic acid resulting in lower saponification number [28]. Quality of produced CNSL is assessed by comparing with CNSL quality standard values of the Indian Institute. Based on this standard, saponification values range from 18-20 mg KOH/100g [4]. However, standard values are intended for raw materials of various chemical industries [29] such as to substitute phenols in the formulation of phenol-formaldehyde adhesives [30], whereas CNSL as an ingredient for pesticides will be better which has a higher saponification value because it shows the content of anacardic acid. Therefore, pure CNSL has a better value than CNSI I and II nanoemulsions (Table 3).

TABLE III

CHARACTERISTIC OF PURE AND NANOEMULSION CNSL

\begin{tabular}{|c|c|c|c|c|c|}
\hline \multirow[b]{2}{*}{ CNSL } & \multicolumn{5}{|c|}{ Variables } \\
\hline & 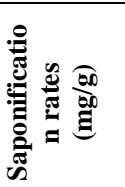 & $\begin{array}{c}\text { Iodine } \\
\text { numbers } \\
(\mathrm{mg} / \mathrm{g})\end{array}$ & $\begin{array}{c}\text { Acid } \\
\text { numbers } \\
(\mathrm{mg} / \mathrm{g})\end{array}$ & $\begin{array}{c}\text { Density } \\
(\mathrm{g} / \mathrm{ml})\end{array}$ & $\begin{array}{l}\text { Viscosity } \\
\text { (cp) }\end{array}$ \\
\hline Pure & 90.4696 & 30.8864 & 106.647 & 1.2500 & 8305.5 \\
\hline Nano-I & 20.4025 & 3.6195 & 5.750 & 0.9059 & 17.0 \\
\hline $\begin{array}{c}\text { Nano- } \\
\text { II }\end{array}$ & 15.7250 & 2.5684 & 6.194 & 0.9556 & 5.15 \\
\hline
\end{tabular}

The number of iodine is expressed as the grams of iod absorbed by 100 grams of oil/fat and used to express the degree of unsaturation of an oil or fat [27]. The double bonds found in unsaturated fatty acids will react with larger amounts of iodine or iodine compounds. The iodine value is an important oil quality parameter and can be used to classify "dryer" and "non-dryer" oils [4], [3]. Drying oils which have higher iodine numbers have better drying power than oils that have low iodine numbers [4]. From the test results of the characteristics of pure CNSL and nanoemulsion I and II, showed that the pure CNSL iodic number is greater than the CNSL nanoemulsion, indicating that pure CNSL is easier to dry but all of them are not classified as drying oil.

Acid number is a measure of the amount of free fatty acids and is calculated based on the molecular weight of fatty acids or fatty acid mixtures [27]. The lower the acid number, the better the oil quality [4]. At the Indian institute standard CNSL acid number values range from 104 to 110 $\mathrm{mg} \mathrm{KOH} / \mathrm{g}$ [4]. Based on this pure CNSL has better quality than nanoemulsions because the value is much greater according to Indian Institute quality standards (Table 3).

Density is important to know the presence of foreign substances in a liquid and other changes that affect its quality [27]. The value of the CNSL quality standard commonly used as industrial raw material (Indian institute standard) is no more than $0.965 \mathrm{~g} / \mathrm{cm} 3$ [4]. However, as a pesticide, a higher density can be more effective due to the unique content with various natural components of the cashew nut shell extract which has higher toxicity [13]. Pure CNSL has a higher density than the nanoemulsions formula, and the results of this study also showed higher toxicity to maize weevil. 
Viscosity of CNSL nanoemulsion has a viscosity that is much smaller than pure CNSL and therefore more easily applied for pest management. Produced CNSL is considered good quality if the viscosity is still below the Indian standard value and the standard the maximum viscosity value of cashew seed oil is $550 \mathrm{cP}$ [4]. The viscosity of pure CNSL is very high and indeed a very thick liquid, so it is more difficult in direct application; therefore, organic solvents are needed to further dilute, as was done in the CNSL formulation in this study.

CNSL quality standards that have been used to this current day are not to be used as plant pest control materials but as industrial raw materials. The use of CNSL as a corn seed treatment insecticide will have different characteristic criteria making standard CNSL quality not fully compatible. For example, their density, CNSL has a higher density than the standard $(0.965 \mathrm{~g} / \mathrm{cm} 3)$, which is $1.25 \mathrm{~g} / \mathrm{cm} 3$ showing many substances involved in the extract, which turned out to be positively correlated with pest control due to a combination of natural substances contained in CNSL.

\section{Anacardic acid identification}

The results of HPLC analysis show the peak of anacardic acid Standard (Figure 3) with a retention time of 1.614 minutes and a standard curve like Figure 4 as well as the standard curve data in Table 4.

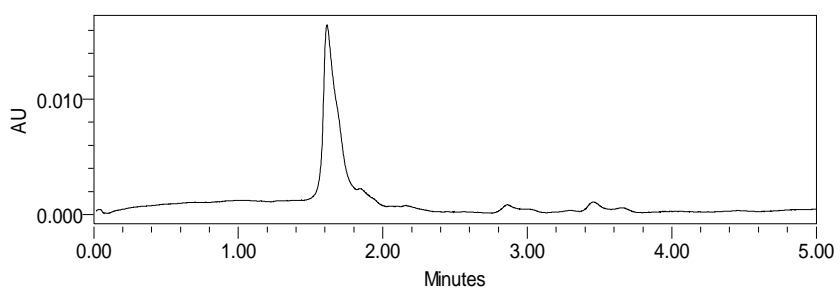

Fig. 3. Peak of anacardic acid standard

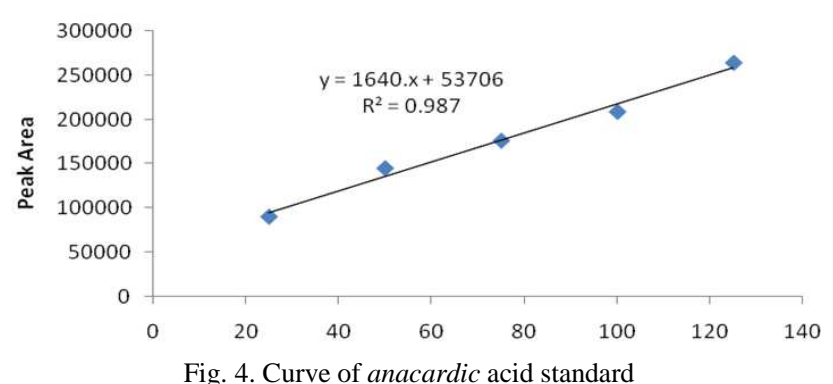

Based on the results of HPLC analysis, pure CNSL and CNSL nanoemulsions contain anacardic acid with varying levels as shown in Table 4.

TABLE IV

STANDARD CURVE DATA OF ANACARDIC ACID

\begin{tabular}{|c|c|}
\hline Concentration (ppm) & Peak Area \\
\hline 125 & 263764 \\
\hline 100 & 208577 \\
\hline 75 & 176024 \\
\hline 50 & 144970 \\
\hline 25 & 90474 \\
\hline
\end{tabular}

Different characteristics between pure and nanoemulsion CNSL can occur due to several factors including extraction methods, differences in varieties and agro-climate conditions where they grow. Extraction methods have a considerable influence on the characteristics of CNSL where the characteristics differences are due to CNSL containing anacardic acid which has thermolabile properties and will decompose into cardanol and carbon dioxide due to the effects of heating [29]. Maximum plant material yield and high purity from extractions mainly depend on the nature of the compound such as thermal stability and the nature of the raw material to be processed [10].

TABLE V

ANACARDIC ACID CONTENT IN PURE CNSL, NANOEMULSI CNSL I AND II FROM HPLC ANALYSIS

\begin{tabular}{|c|c|c|c|c|}
\hline Sample & $\begin{array}{l}\text { Peak } \\
\text { Area }\end{array}$ & Dilution & $\begin{array}{c}\text { Retention } \\
\text { Time }\end{array}$ & $\begin{array}{c}\text { Concentration } \\
(\mathrm{mg} / \mathrm{g})\end{array}$ \\
\hline \multirow{3}{*}{$\begin{array}{l}\text { Pure } \\
\text { CNSL }\end{array}$} & 118789 & $20 x$ & 1.654 & 113.9 \\
\hline & 144798 & $20 x$ & 1.654 & 138.8 \\
\hline & 160592 & $20 x$ & 1.654 & 154.0 \\
\hline \multicolumn{4}{|c|}{ Mean } & 135.6 \\
\hline \multicolumn{4}{|c|}{ SD } & 20.2 \\
\hline \multirow{3}{*}{$\begin{array}{c}\text { CNSL } \\
\text { Nano } \\
\text { Emulsi } \\
\text { on I }\end{array}$} & 31 & $20 x$ & 1.711 & 30.21 \\
\hline & 32 & $20 x$ & 1.712 & 31.56 \\
\hline & 34 & $20 x$ & 1.710 & 33.46 \\
\hline \multicolumn{4}{|c|}{ Mean } & 31.74 \\
\hline \multicolumn{4}{|c|}{ SD } & 1.60 \\
\hline \multirow{5}{*}{$\begin{array}{c}\text { CNSL } \\
\text { Nano } \\
\text { Emulsi } \\
\text { on II }\end{array}$} & 91 & $20 x$ & 3.3 & 88.19 \\
\hline & 84 & $20 x$ & 3.3 & 81.45 \\
\hline & 84 & $20 x$ & 3.3 & 81.46 \\
\hline & 1808 & $20 x$ & 3.3 & 107.22 \\
\hline & 88 & $20 x$ & 3.3 & 85.27 \\
\hline \multicolumn{4}{|c|}{ Mean } & 88.72 \\
\hline \multicolumn{4}{|c|}{ SD } & 10.72 \\
\hline
\end{tabular}

CNSL nanoemulsion I underwent a heating process at $<60^{\circ} \mathrm{C}$, whereas CNSL nanoemulsion II did not. Heat treatment may cause anacardic acid to be decomposed into cardanol and carbon dioxide. These changes can be detected by changes in CNSL $\mathrm{pH}$ from acidic to alkaline conditions. Cardanol compounds have chemical structures similar to phenols, so they have the opportunity to substitute phenol compounds. The difference is that the cardanol compound has an unsaturated branch chain $(\mathrm{C} 15)$ in the meta position of its phenol core [29].

The heating process in CNSL nanosemulsion I cause lower anacardic acid content than CNSL nanoemulsion II (Table 5), and therefore the toxicity of CNSL nanoemulsion I is also lower as indicated by LC50 values (Figure 5) and LC 99 (Figure 6).

\section{Toxicity of CNSL}

Previous studies showed CNSL potential as an insecticide that was able to interfere/inhibit growth and development resulting in pest mortality on seeds. Therefore, CNSL has 
the potential to replace synthetic chemicals as a seed treatment material for corn seeds against Sitophilus sp. and Tribolium sp.. Pure CNSL, requires dilution with organic solvents to obtain the most stable, effective and efficient dosage form due to its very high viscosity

CNSL has a different solubility in some organic solvents used in this study. Based on the solubility test with the percentage of solubility as shown in Table 6, CNSL in acetone has the highest percentage of solubility, then followed by solubility in ethanol and the lowest in methanol.

TABLE VI

CNSL SOLUBILITY IN SOME ORGANIC SOLVENT

\begin{tabular}{|c|c|c|rl|}
\hline \multirow{2}{*}{$\begin{array}{c}\text { Kinds of } \\
\text { Solvent }\end{array}$} & \multicolumn{4}{|c|}{ Solubility (\%) } \\
\cline { 2 - 5 } & Replication 1 & Replication 2 & Mean \\
\hline Methanol & 81.6402 & 81.2285 & $81.4344 \quad$ c \\
\hline Ethanol & 84.2241 & 84.2554 & $84.2340 \quad$ b \\
\hline Acetone & 87.9976 & 87.4684 & $87.7330 \quad$ a \\
\hline
\end{tabular}

Organic solvents solubility percentage used in making CNSL formulations will affect its toxicity. The CNSL formulation with acetone, which has the highest percentage of solubility, causes the highest toxicity compared to ethanol or methanol. This is indicated by the smallest LC50 and LC99 values (Figure 5 and Figure 6).

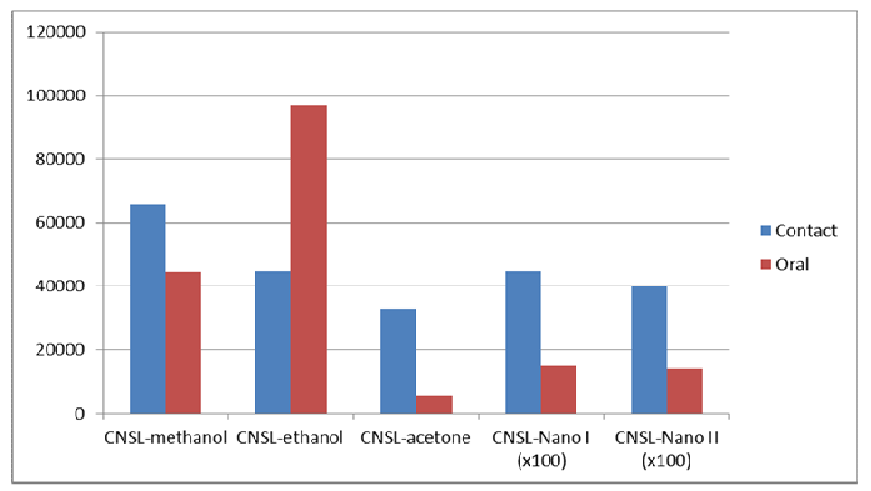

Fig. 5. Toxicity (LC50) of various CNSL formulation

Plant extracts using acetone solvents caused higher mortality of adult pulse beetle Callosobruchus maculatus compared to methanol solvents [31]. Even for the $2^{\text {nd }}$ larval instar, acetone plant extract caused mortality $92.5+7.5) \%$ while with methanol plant extract, which was lower $(62.0+$ 15.7) \%. However, methanol is widely used as a solvent in the extract plant because it is easily obtained and cheaper, and in general also actually provides extract plants that are toxic to insect pests such as botanical extracts of Azadirachta indica (neem) and Gardenia jasminoides (gardenia) against mealybug [32].

CNSL-acetone formulations have LC50 contacts and LC50 feed of 32855 (2466-4036) ppm and 54750 (42876161) ppm respectively and LC99 contacts and LC99 feed of 170480 (120124-310005) ppm and 102985 (80553) - 170598) ppm respectively. The toxicity was lower compared with spinosad which is considered a safe grain protectant including wheat, corn, and rice. Spinosad is a biopesticide derived from naturally occurring soil actinomycete, Mertz and Yao Saccharopolyspora Spinosa (Bacteria: Actinobacteridae). Spinosad contact toxicity against pulse beetle, Calosobruchus Chinensis was higher than CNSL- acetone with LC50 of 117.46 (75.23-185.87) ppm and LC90 of 6016.68 (1688.03-156163.37) ppm [33]. However, CNSL nanoformulation has higher toxicity based on its LC99 value which was <2000 ppm and lower than spinosad's LC90. This shows that nanoemulsion formulation can increase the toxicity of CNSL against maize weevil. The toxicity of CNSL formulation against maize weevil is categorized as a pesticide, As stated in Ref. [1] where the LC50 value $>200$ ppm, it is also said that if the compound has LC50<30 ppm is cytotoxic while LC50 between $30-200 \mathrm{ppm}$ is antimicrobial.

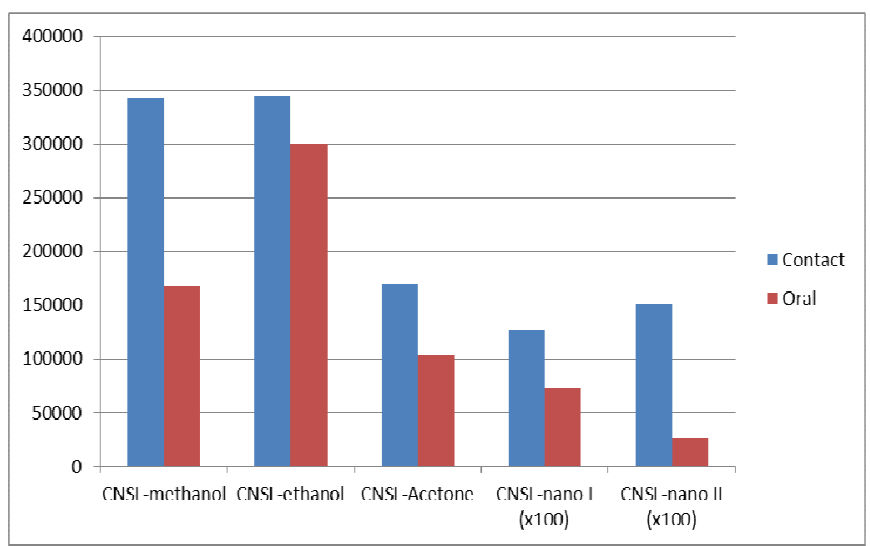

Fig. 6. Toxicity (LC99) of various CNSL formulation

Anacardic acid has much use, including as molluscicide and insecticides. CNSL toxicity due to the content of anacardic acid can inhibit the enzymes prostaglandin, tyrosine and lipoxygenase, as an anti-tumor, and antimicrobial. In addition to pests at low concentrations can be as a contact poison resulting in mortality and egg hatching inhibition. Meanwhile, other research results also showed that CNSL was able to kill larvae and imago Sitophilus sp. of $22.5-50 \%$ at CNSL concentrations of $6.25-50 \%$, which also resulted in an inhibition of $37.5-60 \%$ on the development of larvae into pupae. It also inhibits the development of pupae into imago by $12.5-25 \%$ [34].

\section{CONCLUSION}

The CNSL yield of cashew nutshell extraction in this study ranged from $16.67-21.15 \%$, with an average of $18.43 \%$. The type of organic solvent in the CNSL formulation affects its toxicity to maize weevil Maize weevils. Compared with methanol and ethanol, acetone produced the highest toxicity of CNSL formulations with LC50 contact and LC50 feed of 32855 (2466 - 4036) ppm and 54750 (4287 - 6161) ppm and LC99 of contact and LC99 of feed respectively 170480 (120124 - 310005) ppm and 102985 (80553 - 170598) ppm. The development of CNSL formulations into nanoemulsions has the potential to increase its toxicity to maize weevil. CNSL nanoformulation without heating will have more anacardic acid content so that the toxicity is higher than heating CNSL nanoformulation $\left(<60^{\circ} \mathrm{C}\right)$.

\section{ACKNOWLEDGMENT}

This research is fully supported by using the scholarship funds of the Government of the Republic of Indonesia 
through the Indonesian Institute of Education Scholarship Fund Management Institution (LPDP BUDI-DN) Indonesia. Number: PRJ-4838/LPDP.3/2016.

\section{REFERENCES}

[1] D. Kusrini, and M. Ismardiyanto, “Asam Anakardat dari Kulit Biji Jambu Mete (Anacardium occidentale L.) yang Mempunyai Aktivitas Sitotoksik”. J. Kim. Sains \& Apl. VI (1), pp. 4-6, 2003.

[2] J.E. Mgaya, G.B. Shombe, S.C. Masikane, S. Mlowe, E.B. Mubofu, and N. Revaprasadu, "Cashew Nut Shell: A Potential Bio-Resource for The Production of Green Environmentally Friendly Chemicals, Materials and Fuels". Green Chemistry 21(6), pp. 1186-1201, 2019.

[3] Direktorat Jenderal Perkebunan, "All-In-One Agriculture Information",

http://inaagrimap.litbang.pertanian.go.id/index.php/sentraproduksi/tanaman-buah-buahan/jambu-mete, 2016

[4] S. Kataren, "Pengantar Teknologi Minyak dan Lemak Pangan". UI press. Jakarta, 2012.

[5] A. Cahyaningrum, T. Setyowati, and A. Nur, "Ekstraksi Cashew Nut Shell Liquid (CNSL) dari Kulit Biji Mete". Ekuilibrium V(1), pp. 40 $-45,2006$.

[6] Risfaheri, T.T. Irawadi, M.A. Nur, I. Sailah, Z.A. Mas'ud, and M.S. Rusli, "Optimasi Komposisi Kardanol dari Minyak Kulit Mete sebagai Subtitusi Fenol dalam Formulasi Perekat Fenol Formaldehida”. J.Pascapanen 2 (1), pp. 24-33, 2005.

[7] R. Anand, and B.P. Nair, "Anacardic Acid and Cardanol: Prospective Applications for Cancer Therapy, Drug Delivery, and Imaging”. Springer Link. https://link.springer.com/chapter, 2017.

[8] M. Park, D. Upton, M. Blackmon, V. Dixon, S. Craver, D. Neal, and D. Perkins, "Anacardic Acid Inhibits Pancreatic Cancer Cell Growth, and Potentiates Chemotherapeutic Effect by Chmp1A -ATM-p53 Signaling Pathway". BMC Complementary and Alternative Medicine $18: 71$ https://doi.org., 2018.

[9] J. Towaha, and N.R. Ahmadi, "Pemanfaatan Cashew Nut Shell Liquid sebagai Sumber Fenol Alami pada Industri”. Buletin RISTRI 2 (2), pp. 187-198, 2011.

[10] M. Sofyana, D. Supardan, Zuhra, C.A. Maulida, U. Haura, "Ultrasound Assisted Extraction of Oleoresin from Nutmeg (Myristia Fragrans Houtt)". International Journal on Advanced Science Engineering Information Technology (IJASEIT). Vol.3, No. 4, pp. 18-21, 2013.

[11] I.N. Simpen, "Isolasi Cashew Nut Shell Liquid dari Kulit Biji Mete (Anacardium occidentale L) dan Kajian Beberapa Sifat FisikoKimianya". Ejournal Universitas Udayana. http://ejournal.unud.ac.id., 2008.

[12] D. Sumangat, A. Supriatna, and S. Yuliani, "Rekayasa Teknologi Ekstraksi CNSL Sistem Penggorengan Kontinyu". Balai Penelitian Tanaman Rempah dan Obat, 2007.

[13] D. Astriani, W. Dinarto and W. Mildaryani, "Effect of Extraction Method of CNSL Production and Its Toxicity as Botanical Pesticides to Maize Weevil of Corn Seed Storage". The-3rd International Conference on Green-Agroindustry. UPN "Veteran" Yogyakarta, 2017.

[14] R.B. Paneru and R.B. Thapa, "Screening of promising maize genotypes against maize weevil (Sitophilus zeamais Motschulky) in storage condition". Journal of Maize Research and Development, 3 (1), pp. 108-119, 2017.

[15] N.S.P. Nuryanti, Dadang, E. Martono, and E.S. Ratna, "Pengembangan Formulasi Insektisida Nabati Untuk Pengendalian Wereng Batang Cokelat (WBC) (Nilaparvata lugens Stal.)". Thesis Fakultas Pertanian, Institut Pertanian Bogor (IPB), 2017.

[16] G.S. Germinara, M.G. De Stefano, L. De Acutis, S. Pati, S. Delfine, A. De Cristofaro, and G. Rotundo, "Bioactivities of Lavandula angustifolia essential oil against the stored grain pest Sitophilus granarius". Bulletin of Insectology 70 (1), pp. 129-138, 2017.

[17] G. Thanavendan, S. Jeyarani and J.S. Kennedy, "Safety of Selected Botanical and Synthetic Insecticides Against Braconid Parasitoids of
Vegetable Ecosystems". International Journal of Plant Protection, Vol 10 (1), pp. 174-180, 2017.

[18] M.R. Amin, S.M.A. Shafiullah, E. Mondal and T. Ahmed, "Toxicity and Physiological Effects of Some Plant Extracts On Fruit Fly Infesting Ash Gourd”. SAARC J. Agri., 15(2), pp. 125-135, 2017.

[19] R. Noveriza, M. Mariana, and S. Yuliani, "The efficacy of nanoemulsion formulation of citronella oil against potyvirus causing mosaic disease on patchouli". Bul. Littro, Volume 28, Nomor 1, 2017

[20] L.L. Bergeson, "Nanosilver : US EPA's Pesticide Office Considers How Best to Proceed". Environmental Quality Management, 19, pp. 79-85, 2016.

[21] D.J. Mc Clements, "Nanoemulsions Versus Microemulsions: Terminology, Differences and Similarities". Soft Matter 8, pp. 17191729, 2012.

[22] G.V. Anders, and S.C. Glotzer, "DNA Nanotechnology: The World's Smallest Assembly Line". Nature Chemistry, 4, pp. 79-80, 2012.

[23] N. Arpi, Fahrizal, Satriana, S. Edward, "Extraction and Properties of Gelatin from Spotted Oceanic Triggerfish (Canthidermis maculata) Skin and Bone". International Journal on Advanced Science Engineering Information Technology (IJASEIT). Vol.6, No. 5, pp. 561-567, 2016.

[24] S.H. Yuliani, M. Hartini, Stephanie, B. Pudyastuti, E.P. Istyastono, "Comparison of Physical Stability Properties of Pomegranate Seed Oil Nanoemulsion Dosage Forms with Long-Chain Triglyceride and Medium-Chain Triglyceride as the Oil Phase". Trad. Med. J., 21(2), pp. 93-98, 2016.

[25] A. Taban, M.J. Saharkhiz, and M. Hooshmandi, "Insecticidal and Repellent Activity of Three Satureja Species against Adult Red Flour Beetles, Tribolium castaneum (Coleoptera: Tenebrionidae)". Acta Ecologica Sinica 37, pp. 201-206. www.elsevier.com/locate/chnaes, 2017.

[26] Bett, K. Philip, A.L. Deng, J.O. Ogendo, S.T. Kariuki, M.Kamatenesi-Mugisha, J.M. Mihale, and B. Torto, "Residual Contact Toxicity and Repellence of Cupressus lusitanica Miller and Eucalyptus saligna Smith Essential Oils against Major Stored Product Insect Pests". Industrial Crops \& Products. www.elsevier.com/locate/indcrop, 2017.

[27] L.B. Warsono, W. Atmaka, and B.S. Amanto, "Ekstraksi Cashew Nut Shell Liquid (CNSL) dari Kulit Biji Mete dengan Menggunakan Metode Pengepresan”. Jurnal Teknosains Pangan, II (2), pp. 84-92, 2013.

[28] E.A. Taiwo, "Cashew Nut Shell Oil - A Renewable and Reliable Petrochemical Feedstock". Chapter 1, Advances in Petrochemicals, INTECH, pp. 3-25, 2015.

[29] Risfaheri, T.T. Irawadi, M.A. Nur, I. Sailah, Z.A. Mas'ud, and M.S Rusli, "Pemisahan Kardanol dari Minyak Kulit Biji Mete dengan Metode Destilasi Vakum”. J. Pascapanen (1), pp. 1-11, 2004.

[30] D.J. Garkal, "Review on Extraction and Isolation of Cashew Nut Shell Liquid". International Journal of Innovations in Engineering Research and Technology [Ijiert] 1(1), pp. 1-8, 2014.

[31] D. Kosini, E.N. Nukenine, C. Saidou, A.T. Tchinda, and G.A. Agbor, "Effects of Bioactive Extracts of Ocimum canum (Lamiaceae) on Callosobruchus maculatus (Coleoptera: Chrysomelidae) in Stored Cowpea and Soybean". Acta Entomologica Sinica, 60 (12), pp. 1420-1429, 2017.

[32] H.A. Ghafoor, M. Afzal, M.A. Riaz and M.Z. Majeed, "In-vitro Toxicity Evaluation of some Phytoextracts against Mealybug Drosicha mangiferae (Hemiptera: Pseudococcidae) Infesting Citrus Orchards in Pakistan". Pakistan J. Zool., vol. 51(5), pp 1815-1822, 2019

[33] P. Mondal, M.M. Uddin, and M.T.H. Howlader, "Determination of toxicity of spinosad against the pulse beetle, Callosobruchus chinensis L". J Bangladesh Agril Univ 16(3), pp. 411-416, 2018.

[34] M. Iskandar, "Propek CNSL (Cashew Nut Shell Liquid) sebagai Bahan Baku Industri Insektisida Nabati”. Perkembangan Teknologi Tanaman Rempah dan Obat 14 (2), 2002. 